\title{
MRI を使用した慢性肝疾患の門脈血流速度
}

\section{一Direct bolus imaging 法による測定一}

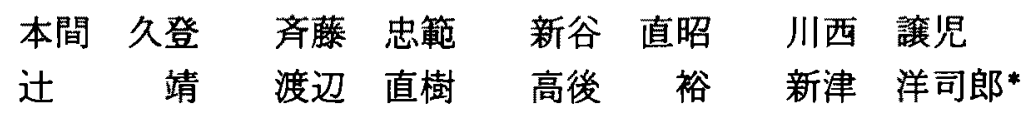

要 旨：Magnetic resonance imaging（MRI）を用いた血流測定法の一つである direct bolus imaging (DBI) 法により，血流速度の基碟的検討をした，さらに，健康成人と慢性肝疾患の門 脈血流速度および血流量の比較検討を行ない，本法の有効性について検討した。

Phantom 実験では, injectorによる流速の実測値とDBI 法による流速値との間で, 上方流が $r=0.997$, 下方流が $r=0.986$ と高い一次相関を得た. DBI 法による聞脈血流速度は, 健康成人, 慢性肝炎，肝硬变症の順に有意に減少した。 李た，門脈一次分岐部に近い程流速の低下傾向を 示した。一方，門脈血流量は肝㵶維化が増す病態程低下する傾向を示した。これより，門脈血 流速度の測定は，慢性肝疾患の病態を把握する上で有用な検査法と考えられた。

索引用語： 門脈血流速度 MRI DBI 法 慢性肝疾患

緒言

肝臓の門脈血行動態の評価は，各種肝疾患に㧍ける 病態を把握するらえで重要と考えられ，種々の測定方 法が試みられてきた ${ }^{1-3)}$.この中で，最近その応用範囲 が急速に拡がった MRIに上る血流速度の映像化は， MRI で得られる多彩な情報の中でも最む興味あるむ のの一つであり，具体的には，励起ハルスの出入りに よる信号強度の変化を利用する方法 (time-offlight) ${ }^{4,5)}$ ，信号の位相偏移より流速を計算する方法 ${ }^{6,7)}$ （phase shift）など数多く報告されている.

本研究では，血液ボーラスを励起面の垂直方向から 見る事によりその移動を直接映像化した direct bolus imaging (DBI) 法早10) 使用して流速の基礎的検討を 行なった上で，慢性肝疾患の門脈血流速度の測定にお ける本法の有用性について検討したので報告する。

対象およU゙方法

\section{1. 装置と攝影条件}

機種は0.5T 超卮導型（SMT-50，Shimazu）を使用 した. 門脈描出のための pilot scanはspin echo法 （TR 160msec，TE 23msec）で行なった．積算回数は 1 回, マトリックスは $128 \times 128$, 励起面のスライス幅 は5 10mm で，心電同期装置を併用した．血流速度の

\footnotetext{
- 札蜆医科大学第 4 内科
}

〈受付日1990年 3 月16日 $>$ パルス采列は，field echo 法9.10)を用い各々の心時相で の流速は，ECGの R 波から70msec 毎に，0，70，140， $210 \mathrm{msec}$ と選択励起しそれぞれの $\mathrm{R}$ 波より $50 \mathrm{msec}$ 後 の DBI 像をもとに算出した。

なお DBI 法の原理は、Shimizu 等の方法に基き血流 移動を直接画像化し、その移動距離より流速を算出し た

\section{Phantom 実験}

DBI 法による流速値と実測値との相関を調べるた め，U一字 flow phantom 実験を行なった，Phantom 実 験には injectorに内径 $10 \mathrm{~mm}$, 断面積 $0.785 \mathrm{~cm}^{2}$ のシリ コンチューブを接続して用いた(Fig. 1).すなわち， 予め一定の速度に設定した injector より $5 \mathrm{mmol} の$ 塩 化ニッケル水溶液を流し，DBI法でその流速を測定し た.

\section{3. 対象症例}

正常肝11名，慢性肝资17名，肝硬変症23名の計51应 例である。門脈血流は，朝より絶食にし，午前10時頃 安静臥床状態で測定した。

\section{4. 門脈本幹の描出}

まず肝惦横断面の pilot scan 後, 上腸間膜静脈から 門脈本幹移行部の横断面と門脈一次分岐部直前の横断 面像の 2 枚の画像よりダブルオブリークで門脈本幹の 走行に治った画像を撮像した。

\section{5. 門脈血流速度の測定方法}


A

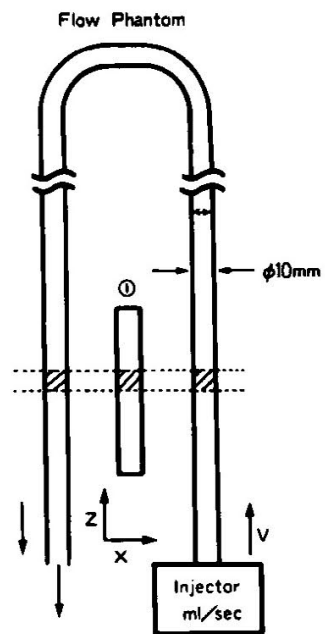

B

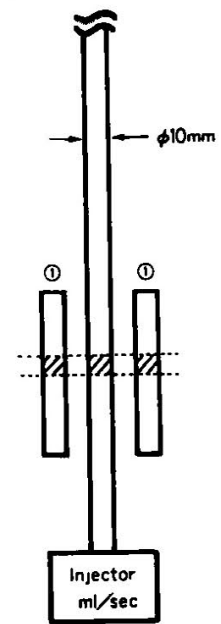

Fig. 1 Flow phantom study. A U-shaped tube (A) and straight tube (B) of inner diameter $10 \mathrm{~mm}$ are shown. (1) indicates tubes filled with $\mathrm{NiCl}_{2}$ solution, and the broken lines indicate the excited planes.

励起面は門脈本幹に対し, 門脈一次分岐部直前 (P. 1)，門脈中間部（P-2），上腸間膜静脈より門脈への移 行部 (P-3)の 3 力所で流速を測定した (Fig. 2). 移動 距離の計算は画像上の流体を含む関心領域を ROIで 囲み、その信号の median 值を平均移動距離とし，それ を TEで除すことで流速を求めた9!

\section{6. 門脈血流量の測定}

門脈本幹の走行に沿った画像より,P-2部位の断面を 描出し、マニュフルでトレースする事により門脈本幹 の断面積を算出した，血流量は，門脈の流速に断面着 を掛けて得た。

\section{結果 \\ 1. Phantom 実験}

Fig. 3 は，U-字 flow phantom (Fig. 1A) を使用し た DBI 法による励起 $50 \mathrm{msec}$ 後の画像である。 上方と 下方へのボーラスが明瞭に可視下できる。また，予め injector に設定した流速值と DBI 法より求めた流速 値の相関係数は, 上行流が0.997, 下行流が 0.986 と高 い相関を示した（Fig. 4)，次に，DBI 法の測定条件に
$\mathbf{A}$

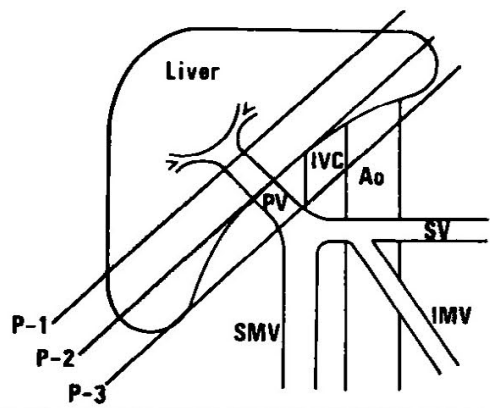

C

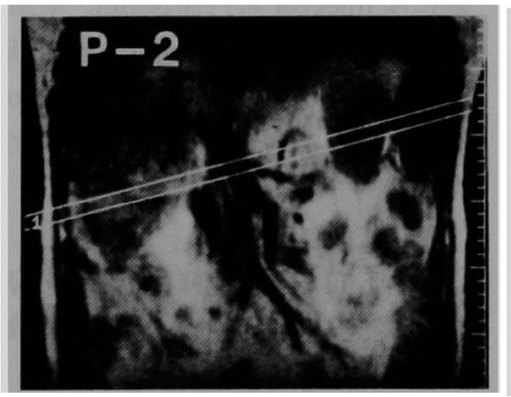

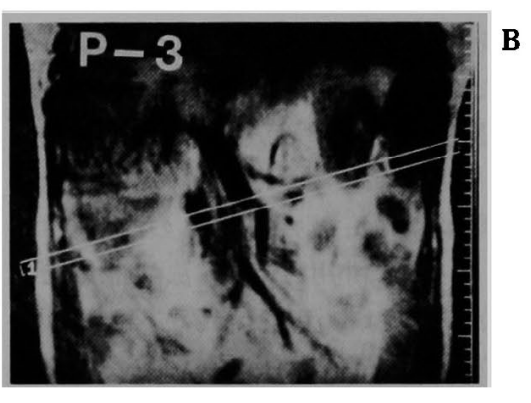

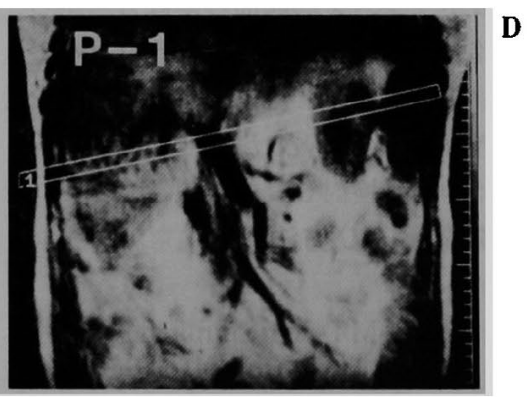

Fig. 2 Exicited planes in portal vein observation. Part A shows the three positions of the excited planes used in measurement of portal blood flow velocity. Parts $B, C$ and $D$ show the images obtained by double oblique projection, with B, C and D corresponding to the excitation sites P-3, P-2 and P-1, respectively, of the excited plane. The following abbreviations are used; Ao: descending aorta, IMV : inferior mesenteric vein, IVC: inferior vena cava, SMV : superior mesenteric vein, $\mathrm{PV}$ : portal vein, $\mathrm{SV}$ : splenic vein 


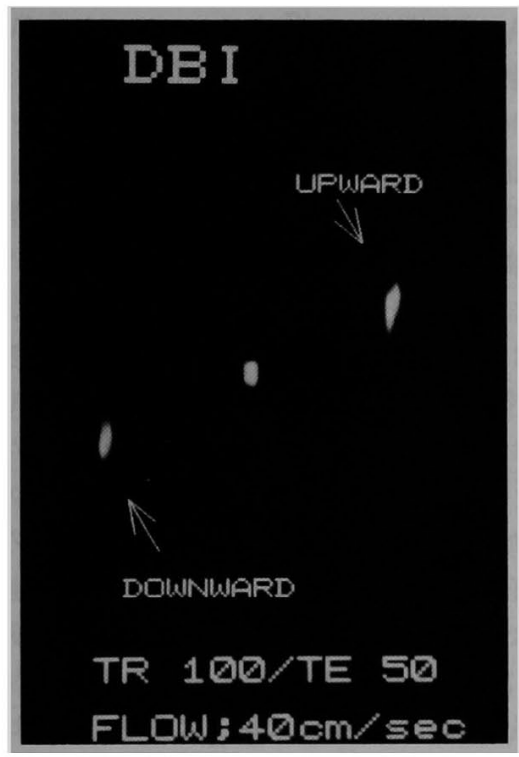

Fig. 3 Flow imaging. The arrows indicate the fluid boluses flowing upward and downward 50 msec after excitation.
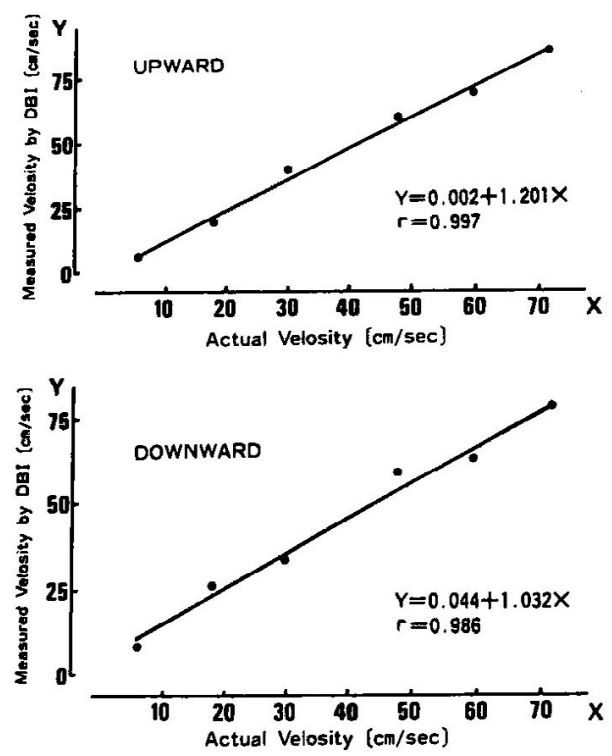

Fig. 4 Correlations between flow velocities preset with the injector and flow velocities measured by the DBI method.

よる流速の変化を調べる目的で，異なる TEによる流 速の影響を検討した。

この結果，TE50〜 150msecの間で測定した流速值 は，実測値とほとんど変化が認められなかった（Fig.

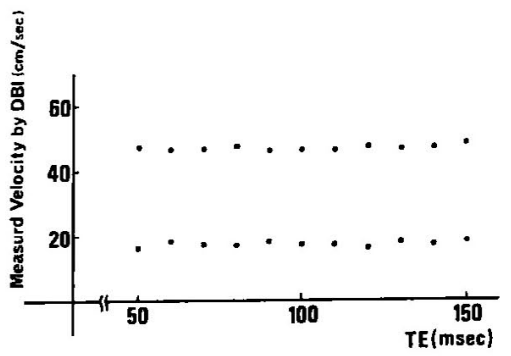

Fig. 5 Relation between changes in time $T E$ and variations in flow velocities measured by $\mathrm{DBI}$ method.

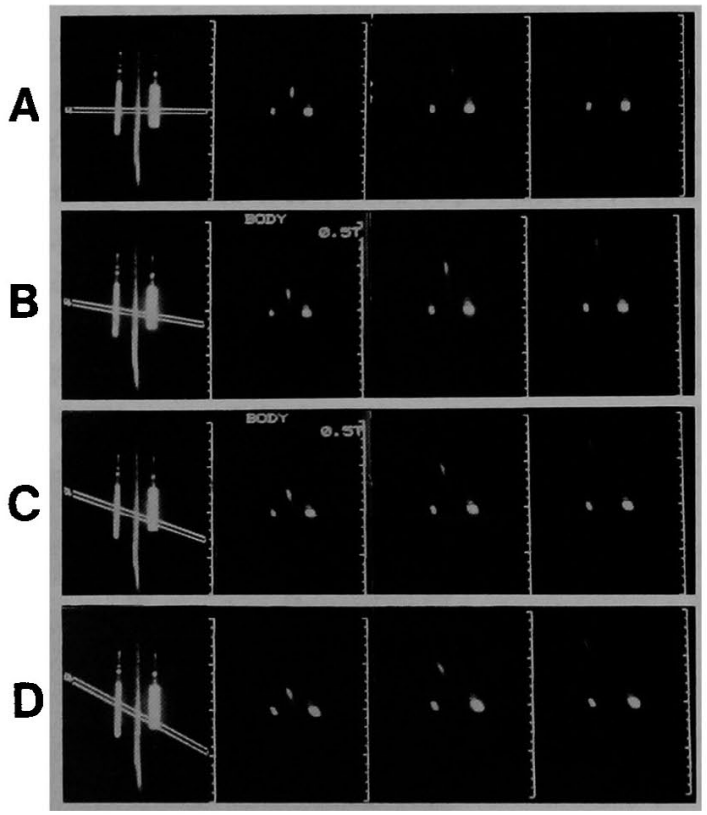

Fig. 6 Flow images obtained for varied angles of inclination between excited plane and direction of flow. A : $0^{\circ}, \mathrm{B}: 15^{\circ}, \mathrm{C}: 30^{\circ}, \mathrm{D}: 40^{\circ}$

5).また，門脈血流速度測定の際，心拍による artifact を避けるため励起面を心葴にはいらないように選択す ると, 励起面は門脈長軸方向に対しある角度を有する. この角度で測定した流速值が正確な值を示すかどらか を検討するため，流速方向と励起面の交文角度を変え て直線 flow phantom (Fig. 1B) で測定した (Fig. 6). この流体長軸方向に対し励起角度を变えた時の流速值 は，Fig. 7 に示すよ5に，角度が 0 ～30度ではほとん ど変化が認められなかった。

2. 血流像

DBI 法にて描出された門脈 (PV)，下大静脈 (IVC) 


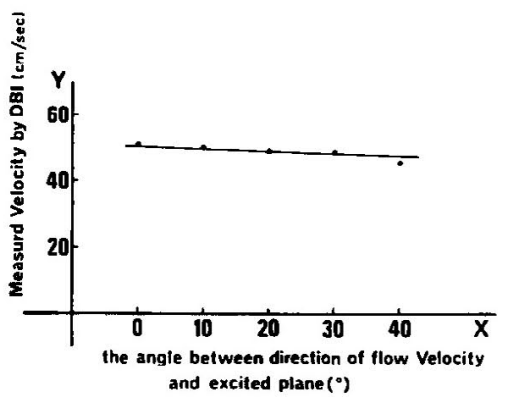

Fig. 7 Dependence of flow velocity measured by DBI method upon angles of inclination between excited plane and direction of flow.

および行大動脈 $(\mathrm{Ao}$ ) の血流像を Fig. 8 に示す。こ れは，ECGの R 波をトリガーとして70msec 每に選択 励起し，R 波よりそれぞれ0，115，230，345，460 $\mathrm{msec}$ 後に得られた画像である。励起面がPV，IVC拉よび A。の長軸方向に対しある角度を有するため, 各ボー ラスは左斜上行流か PV, 右斜上行流か：IVC, 左斜下行 流がAoを示す。この連続画像より, PV の流速は定常
流で，Aoは拍動流である事がわかる，なお IVCは， 本来拍動流を示すが励起面にIVCが入らないため, ゴースト像が認められる。

\section{3. 門脈血流速度}

Fig. 9 はそれぞれの心時相の流体移動距離上り求 めた脈波パターンを示す。健康成人の部位別門脈血流 速度は，それぞれP.3で18.1士4.3cm/sec，P.2て $16.8 \pm 3.7 \mathrm{~cm} / \mathrm{sec}, P-1 て ゙ 15.0 \pm 2.4 \mathrm{~cm} / \mathrm{sec}$ であった。 これは慢性肝炎および肝硬変症でも同様な傾向を示 し，P-3>P-2>P-1の順に速い流速を示した（Fig. $9 A)$. 次に, 慢性肝炎㧍よび肝硬変症のP-2部位におけ る門脈血流速度の脈波パターンを調べたところ（Fig. 9B). 肝䁍の㵶維化の進行と供に明らかな流速の低下 を認めた。これら正常肝, 慢性肝炎および肝硬変症の P-1，P-2㧍よぴP-3部位の門脈血流速度の平均値と標 準偏差をるとめたのを Table 1 に示す。これより健康 成人, 慢性肝炎おょび肝硬变症の間で, 各々流速の有 意差（ $p<0.05 ） を$ を認めた。

4. 門脈血流量

P-2部位の門脈血流速度とその断面積より测定した

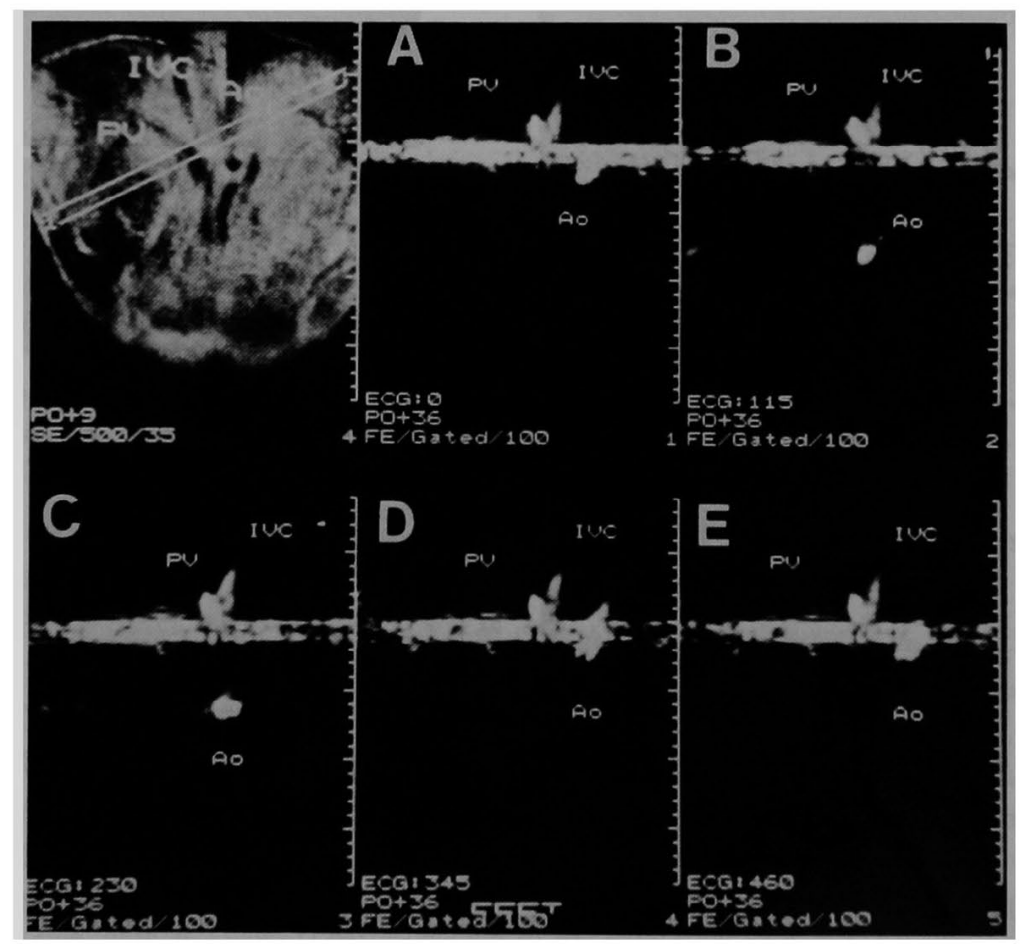

Fig. 8 Serial flow images obtained from ECG-gated coronal images (P-2) These images were obtained by repeated excitation after intervals of $0,115,230,345$ and $460 \mathrm{msec}$, respectively. 
A
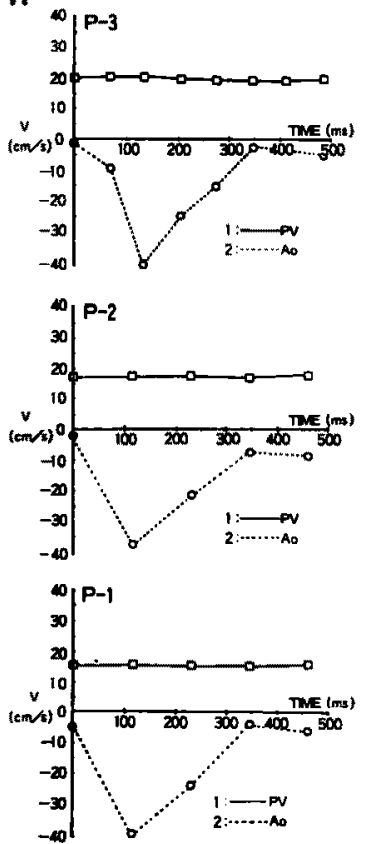

B
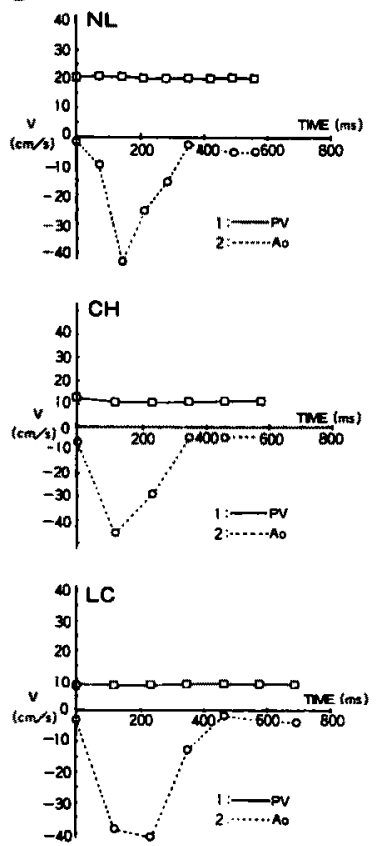

Fig. 9 Flow velocities for respective cardiac phases. The abscissas represent TE and the ordinates represent flow velocity. Ascending boluses are indicated by + and descending by - . Panel A shows the blood flow velocity patterns in the portal vein and abdominal aorta of healthy adults at the sites P-3, P.2 and P-1, respectively (top to bottom). Panel B shows the blood flow velocity patterns in the portal vein (PV) and abdominal aorta (Ao) of healthy adults, chronic hepatitis patients and liver cirrhosis patients, respectively (top to bottom).

健康成人，慢性肝炎および肝硬变应の門脈血流量は， それぞれ $15.3 \pm 5.8 \mathrm{ml} / \mathrm{min} / \mathrm{kg}, 14.5 \pm 4.1 \mathrm{ml} / \mathrm{min} /$

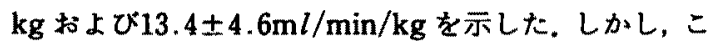
れらの間には有意差を認めなかった。

\section{考察}

肝浻は特有な血管系をるち，機能血管である門脈と， 栄羔血管である肝動脈の両者からら血液の供給を受けて いるが：この血液量の70\%は門脈に，30\%は肝動脈に 由来する，従って，僈性肝疾患における門脈血流速度 の評価は，その病熊と肝窚への血液供給量を推定する 上で重要である ${ }^{11,12)}$ ，今回，MRIによる血流測定法の 一つである DBI 法を使用して，まず phantomによる 流速の基礎的検討を行なった。この結果，DBI 法によ
Table 1 The Blood Flow Velocities in the Portal Vein Caliculated by Means of MR imaging.

\begin{tabular}{l|c|c|c}
\hline & $\begin{array}{c}\mathrm{P}-3 \\
(\mathrm{~cm} / \mathrm{sec})\end{array}$ & $\begin{array}{c}\mathrm{P}-2 \\
(\mathrm{~cm} / \mathrm{sec})\end{array}$ & $\begin{array}{c}\mathrm{P}-1 \\
(\mathrm{~cm} / \mathrm{sec})\end{array}$ \\
\hline Nomal liver & $18.1 \pm 4.3$ & $16.8 \pm 3.7$ & $15.0 \pm 2.4$ \\
\hline Chronic hepatitis & $15.8 \pm 4.9$ & $14.1 \pm 5.1$ & $12.8 \pm 5.7$ \\
\hline Liver cirrhosis & $13.9 \pm 3.7$ & $11.9 \pm 3.5$ & $10.7 \pm 2.8$ \\
\hline \multicolumn{4}{|c}{$\mathrm{p}<0.05$}
\end{tabular}

ろ流速は injectorのそれと比較して，上行流が0.997， 下行流が0.986と高い相関を示した. DBI 法では, 一般 にTEを長くすると流体の信号強度が低下し，逆に TEを短くすると，励起面から血流ボーラスの分離が 不充分になる.しかし，TEが50 150msec の間で湘定 した流速値は，汪とんど变化せず一定の值を示した (Fig. 5).

また，実際に門脈血流速度を測定する際，心拍動に よる artifactを避けると，励起面は門脈長軸方向に対 し垂直でなく，ある角度を有する。この条件で測定し た流速值が正確な速度を反映するかどうかを検討した 結果 (Fig. 6)，角度か330度以内では流速にはとんど影 整を及ぼさない事が明らかとなった(Fig. 7)。それ故， DBI 法で流速を測定する際，励起面と門脈長軸方向は 必ずしも垂直にする必要は無く( $<30$ 度), 流体の移動 距離の励起面に対する垂直べクトル成分を測定する事 で，正しい流速を反映する事が判明した。

次に，DBI 法を用いて健康成人と僈性肝疾患の部位 別門脈血流速度を検討したところ (Fig. 9A)，いずれ む，P-3>P-2>P-1の順に速い㑯向を示した。 この理由 としては，P-3ではSV の流入により流速が早くなるの に対し，P-1では門脈一次分岐部に衝突した乱流などに よって流速が低下した事によるるのと推定される。 従って, 種々の病態で門脈血流速度を比較する際は， その測定部位を一定にする必要があると考えられる。 慢性肝资および肝硬変症のP-2部位における門脈血流 速度の検討では（Fig. 9B），正常肝のそれに比較し

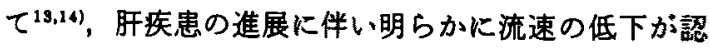
められた。この流速の低下性，門脈域の瀻維性変化の 拡大以より末梢血管の抵抗性が增大する事により生し たものと推定される15,16).

一方, 健康成人, 僈性肝炎および肝硬变症の門脈血 流量の検討では，肝織維化が增す病態程，血流量が低 下する傾向を認めた。しかし，それでれの間に有意差 は無かった。これは，肝織維化の程度が強くなり末梢 
血管の抵抗性が増す肝硬変症程, 門脈の断面積が増加 (抬張)するためめ，流速が低下しても血流量が保たれて いる事が原因と考えられる。従って，門脈血流量上り はむしろ末梢血管の抵抗性を反映すると考えられる門 脈血流速度の方が, 肝緎維化の程度を推定する上で有 用と考えられる。

この門脈血流速度の測定は, 近年, わ5一つの非観 血的測定法である超音波ハルスドッブラー法と断層法 の両者を用いて測定されてきだ7-201.この方法によっ て測定した門脈血流速度は, 健康成人が約 $11 \sim 21 \mathrm{~cm} /$ $\sec ^{18,19)}$, 肝硬变症が約 $9 \sim 14 \mathrm{~cm} / \mathrm{sec}^{18,19)}$ とされてお り,今回の我々の DBI 法による測定値と近似してい る.

しかし，超音波検查法被検者の皮下脂肪や消化管 ガスによってドップラービームが通過しないため，被 検者によっては測定が不能となる。また血管に対し ビームの入射角のずれでサンプリンク位置が異なり， そのボリューウムが変わるため平均流速を出すのが困 難である，などの問題がある.これらの問題に対して, MRI 検查は通常の MRI 検查禁忌例以外のどんな被検 者でも測定可能であり，また血管内血流の平均流速を 測定しているといら点で超音波検査より有用と考えら れる。 それ故, MRIによる流体の測定は，今後，ます ますその応用範囲が拡がっていくものと考えられる。

\section{結論}

MRIによる血流測定法の一つである DBI 法を用い て, 慢性肝疾患の門脈血流速度を测定し, 健康成人と 比較検討した。この結果, 慢性肝炎, 肝硬变症と肝緎 維化の程度が強い病態程, 門脈血流速度の低下を認め た.

\section{文 献}

1) Bradley SE, Ingelfinger FJ, Bradley GP, et al : The estimation of hepatic blood flow in man. $J$ Clin Invest $24: 890-897,1945$

2) Huet $P M$, Lavoie $P$, Viallet $A$ : Simultaneous estimation of hepatic and portal blood flow by an indicator dilution technique. J Lab Clin Med $82: 836-846,1973$

3) Villeneuve JP, Huot $R$, Marleau D, et al: The estimation of hepatic blood flow with in. docianine green: Comparison between the contaneous infusion and single injection methods. Am J Gastroenteol 77 : 233-237, 1982

4) Singer JR, Crooks LE: Nuclear magnetic resonance blood flow measurement in human brain. Science $221: 654-656,1983$

5) Wehrli FW, Shimakawa A, Gullberg GT, et al: Time-of-flight MR flow imaging: Selective saturation recovery with gradient refocusing. Radiology 160 : 781-785, 1986

6) Bryant DJ, Payne JA, Firmin DN, et al: Measurement of flow with NMR imaging using a gradient pulse and phase difference technique. J Comput Assist Tomogr 8: 588-593, 1984

7) Axel $L$ : Blood flow effects in magnetic reso. nance imaging. AJR 143 : 1157-1166, 1984

8) Moran PR, Moran RA, Karstaedt N : Verification and evaluation of internal flow and motion. Radiology 154 : 433-441, 1985

9) Shimizu K, Matsuda $T$, Sakurai $T$, et al: Visualization of moving fluid: Quantitative analysis of blood flow velocity using MR imaging. Radiology 159: 195-199, 1986

10) Matsuda $T$, Shimizu K, Sakurai $T$, et al : Measurement of aortic blood flow with MR imaging : Comparative study doppler US. Radi. ology $162: 857-861,1987$

11) Conn HO, Groszmann RJ: The pathophysiology of portal hypertension. In: The Liver; Biology and Pathobiology, Edited by I Arias, H Popper, D Schachter, DA Shafritz. Ravan Press, New York, 1982, p821-848

12) Groszmann RJ, Kravetz D, Parysow O : Intrahepatic arteriovenous shunting in cirrhosis of the liver. Gastroenterology $73: 201-204,1977$

13）宮内嘉玄，尾崎光泰，仙波芳樹，他：MRI K上る 門脈血流速度測定。日磁医誌 $8: 184-188,1988$

14）玉田 尚, 森安史典，小野成樹，他：磁気共鳴映像 （MRI）による門眽血流速度の検討。日消誌 86 ： $1654-1660,1989$

15) Desmet V : Chronic hepatitis (Including primary biliary cirrhosis). In : The Liver, Edited by EA Gall, FK Mostofi. The Williams \& Wilkins Company, Baltimore, 1973, p286-341

16) Sherlock $S$ : Active chronic hepatitis. In: The Liver, Edited by EA Gall FK Mostofi. The Williams \& Wilkins Company, Boltimore, 1973, p342-360

17) Gill RW : Pulsed doppler with B-mode imaging for quantitative blood flow measurement. 
Ultrasound Med Biol 5 : 223-225, 1979

18) Ohnishi K, Saito $M$, Koen $H$, et al: Pulsed doppler flow as a criterion of portal venous velocity: Comparison with cineangiographic measurements. Radiology $154: 495-498,1985$

19) Zoli M, Marchesini G, Cordiani MR, et al: Echo-doppler measurement of splanchnic blood flow in control and cirrhotic subjects. J Clin
Ultrasound $14: 429-435,1986$

20) Shiraki S, Tsukada K, Ozeki N, et al: Measurement of portal blood flow by an ultrasonic duplex system composed of a pulsed doppler flowmeter and a linear-type real time $B$ mode electroscanner. Gastroenterol Jpn $23: 37-43$, 1988

\section{Portal venous blood flow velocity in chronic hepatic disease - measurement using magnetic resonance imaging-}

Hisato Homma, Tadanori SaItoh, Naoaki ShIntani, Johji KawanishI, Yasushi TsujI, Naoki Watanabe, Yutaka KoHgo and Yoshiro NirTsu*

The direct bolus imaging (DBI) technique using magnetic resonance imaging (MRI) was used to compare portal blood flow velocity and flow volume in 11 healthy adults and 40 patients with chronic hepatic diseases. Portal blood flow measured by the DBI method decreased from healthy adults to chronic hepatitis patients to hepatic cirrhosis patients, in that order. Moreover, blood flow velocity tended to decrease with proximity to the primary bifurcation of the portal vein, and also tended to diminish with increasing severity of hepatic fibrosis. These results indicated that measurement of portal blood flow velocity using MRI constitutes a useful technique for the assessment of morbidity in chronic hepatic disease.

* The Fourth Department of Internal Medicine, Sapporo Medical College (Sapporo) 